\title{
The White and the Black Magician
}

The Light and the Dark side of Spirit

Gitz-Johansen, Thomas

Published in:

Jung Journal

DOI:

10.1080/19342039.2020.1781529

Publication date:

2020

Document Version

Peer reviewed version

Citation for published version (APA):

Gitz-Johansen, T. (2020). The White and the Black Magician: The Light and the Dark side of Spirit. Jung Journal, 14(3), 233-250. https://doi.org/10.1080/19342039.2020.1781529

\section{General rights}

Copyright and moral rights for the publications made accessible in the public portal are retained by the authors and/or other copyright owners and it is a condition of accessing publications that users recognise and abide by the legal requirements associated with these rights.

- Users may download and print one copy of any publication from the public portal for the purpose of private study or research.

- You may not further distribute the material or use it for any profit-making activity or commercial gain.

- You may freely distribute the URL identifying the publication in the public portal.

Take down policy

If you believe that this document breaches copyright please contact rucforsk@kb.dk providing details, and we will remove access to the work immediately and investigate your claim. 
$<$ LRH $><$ journal title font $>$ Jung Journal: Culture \& Psyche $<$ journal title font $>14: 3$ / Summer $2020<$ LRH $>$

$<$ RRH $>$ Thomas Gitz-Johansen, The White and the Black Magician $<$ RRH $>$

$<$ CT $>$ The White and the Black Magician $<$ CT $>$ $<$ SUBTITLE $>$ The Light and the Dark Side of Spirit $<$ SUBTITLE $>$ $<$ CA $>$ Thomas Gitz-Johansen $<$ CA $>$

A couple of years ago I had the following dream:

I am either on a journey or running away from something. In the dream, it is clear that I am on good terms with a figure called the white magician, but I am pursued by the black magician. I come to a field, which I know from my childhood. On the field stands a writing desk, or perhaps it is a pulpit, and I try to hide under it and I hope that the black magician will not find me. However, it turns out the black magician has already found me. He is inside a round talisman that I hold in my right hand. I hurry back in the direction I came from. I fly close to the ground. I hold the talisman containing the black magician as far away from my body as I possibly can, but I do not know what to do with it because I'm afraid that he will get out if I let it go.

As I woke up from the dream, I felt deeply worried by the figure of the black magician. Did it mean, I wondered, that I am disavowing a dark side of myself? Am I identifying with some kind of moral "goodness" (the white magician), and trying to run away from a much more sinister side of my personality and behavior? And not least, what exactly do the figures of the white and the black magician symbolize? 
As I pondered the meaning of the dream, I came across a passage in "The Phenomenology of the Spirit in Fairytales" (Jung 1948/1959, CW 9i) in which Jung mentions the figure of the magician as a symbol of the human spirit. Furthermore, in Jung's many discussions of the phenomenon of spirit he often mentions that it is a most ambiguous phenomenon, which sometimes influences our lives for the better and sometimes for the worse, as seen from a human standpoint. But if it is true that spirit has an ambiguous nature, what are the positive and negative aspects of the work of spirit? And what is this thing called spirit anyway? I believe that the question posed by this dream is not only relevant to me as a person but also has a wider relevance, since it has to do with the thoughts we have and the words we use to make sense of our lives and the world around us.

\section{$<1>$ The Ambiguous Phenomenon of Spirit $<1>$}

Spirit is, by definition, an insubstantial aspect of life, but according to Jung, this neither subtracts from its reality nor its importance for our lives. Jung defined spirit in this way: "just as the 'living being' is the quintessence of life in the body, so 'spirit' is the quintessence of the life of the mind" $(1926 / 1960, \mathrm{CW} 8,9621)$. This means that spirit is that insubstantial part of us that makes us feel alive. Spirit is the breath of God (рneuma) that wakens the inanimate matter and makes it come alive (1931/1960, CW 8, $₫ 664)$. To Jung spirit is closely connected to life itself, and more precisely it is connected to mental and psychological life. Spirit has to do with ideas and visions, faith and philosophies, intellectual creativity and inspiration, all of which enable us to make sense of ourselves and the world around us. The reality of spirit is what makes us more than the biology and chemistry of our bodies and brains. In Jung's words, spirit is what gives life its meaning apart from all the practical and material demands of our everyday lives: "Life and 
spirit are two powers or necessities between which man is placed. Spirit gives meaning to his life" (1926/1960, CW 8, \648). Since spirit in this way is connected to finding meaning in life, this aspect of our psyche is hardly something we can afford to ignore: "Only a life lived in a certain spirit is worth living. It is a remarkable fact that a life lived entirely from the ego is dull not only for the person himself but for all concerned. The fullness of life requires more than just an ego; it needs spirit" (\645).

However, even though the phenomenon of spirit is closely connected to feeling alive and finding meaning in life, the work of spirit is not necessarily positive. At the Nietzsche seminars during the 1930s Jung discusses the spirit in relation to the figure of Zarathustra, which both inspired and destroyed Nietzsche (1989). According to Jung, Zarathustra is a personification of spirit. At these seminars, Jung also discusses how Wotan, a wild and dangerous aspect of spirit, is lose in Germany and threatens to cause havoc and disaster, if its savage but invigorating energies are not tamed and put to positive use. In these discussion Jung both recognizes the vitalizing, invigorating, and inspiring aspect of spirit, and he notices how the unleashed psychological energy may act to enrich as well as destroy human lives and communities. Jung does not claim that spirit itself is either good or evil; he describes it more like a natural phenomenon such as wind, water, or fire, which can sometimes be useful and sometimes be dangerous as seen from a human perspective: "spirit is not necessarily evil; we would have to call it morally indifferent or neutral” (1948/1959, CW 9i, \394). As I will discuss, I suggest that because spirit works through us, it is our attitude toward spirit and how we use it that can be called either positive or negative. 
I also inquire further into the nature of spirit by looking more closely at the double figure of the white and the black magician. I will first present Jung's discussions of the figure of the magician and the image of the two magicians. To examine their literary corollary, I then discuss the figures of the white and the black magician as they appear in the Earthsea novels by Ursula K. Le Guin, which I feel serve as an amplification of the problem of how we relate to spirit.

The Earthsea novels are about a journey of development, in which the protagonist, a magician named Ged, faces the collective spiritual shadow and, as a result, undergoes a development in his own relationship with spirit. The land is enriched and revitalized by his journey. Before continuing, I need to make an important disclaimer. Readers may legitimately point out that identifying our relationship with spirit with the male figure of the magician is gender biased. What about women's relationship to spirit? Is spirit a predominantly male thing? In the two last books of the Earthsea Cycle, Le Guin explores the question of women's (or “the feminine's”) relationship with spirit. She does this especially by discussing the differences between the magic of wizards and witches. This aspect of the gender issue deserves an in-depth analysis in its own right; however, because it is predominantly developed later in the Earthsea story, I do not discuss it here.

\section{$<1>$ The Magician $<1>$}

In his essay "The Phenomenology of the Spirit in Fairytales" (1948/1959, CW 9i), Jung mentions a variety of guises in which spirit may appear. Spirit is frequently related to wind and breath; therefore, it is often symbolized by birds such as eagles or, as in the case of the Holy Spirit in the Bible, as a dove that descends from heaven. Another frequent image of spirit is the figure of the 
wise old man as magician who represents a superordinate consciousness who gives the hero a crucial piece of advice or insight. Elsewhere, the figure of the magician has been discussed as an archetype in its own right (Granrose 1996; Moore and Gillette 1991). Here, I follow Jung's lead and treat the magician as connected with the archetype of spirit. However, rather than understanding the figure of the magician as symbolizing spirit itself, I understand the magician as an image of our relation to and attitude toward spirit. Such an understanding allows a discussion of the importance of the attitude we take toward spirit rather than only talking about spirit in archetypal terms, as does Jung. This distinction makes it possible to discuss the phenomenon of spirit in the light of interpersonal dynamics and relationships. Jung saw spirit as a universal archetype, which appears crossculturally in symbolic materials such as fairy tales, the Bible (the Holy Spirit), literature (especially Nietzsche's Zarathustra), and alchemical texts (Gitz-Johansen, in press). By turning my attention toward the attitude to spirit rather than the archetype of spirit itself, I can discuss how psychological development influences our relationship with spirit and how we use it. This perspective is close to what Knox (2003) and Merchant $(2006,2019)$ have termed the emergent or developmental approach to archetypes. Using this perspective, magic can be understood as an image of the archetype of spirit, whereas the figure of the magician and how the magician relates to and uses magic is an image of the way we relate to spirit.

In myths and fairy tales, the magician is a figure who acts as a willing channel of invisible but powerful forces. The magician taps into the energy of creation and gives it shape and form in the outer world. Understood symbolically, the magician is a figure who gives meaning to the world, or in the words of Jung, "He is . . . an immortal daemon that pierces the chaotic darkness of brute 
life with the light of meaning” (1954/1968, CW 9i, 977). The magician is a bringer of consciousness to the unconscious; he names the yet unnamed, makes sense of chaos, and brings light into the darkness. As such, the magician is a fitting representation of the archetype of spirit that, according to Jung, is synonymous with the archetype of meaning (\$79).

\section{$<1>$ The Black and the White Magician $<1>$}

Because archetypes are like forces of nature, they do not conform to our human standards of good and evil. The archetype of spirit is no exception to this rule, and thus Jung remarks, "Like all archetypes it has a positive and a negative aspect” (1954/1968, CW 9.1, \79). Elsewhere he writes, "The spirit is really a tremendous adventure—cruel, inexorable, inhuman" $(1989,862)$. To Jung, the white and black magicians symbolize the dual sides of the spirit archetype: "The two magicians are, indeed, two aspects of the wise old man, the superior master and teacher, the archetype of the spirit, who symbolizes the pre-existent meaning hidden in the chaos of life" (1954/1968, CW 9i, ๆ74). Taken together, they form what Jung would call a "duplex-figure," which is a figure that contains its own antithesis. The spirit of Mercurius, a central figure of medieval alchemy, is an image of the ambiguous nature of the spirit archetype and of the figure of the magician: "Mercurius is duplex, i.e., he is himself an antithesis. Mercurius or Hermes is a magician and god of magicians” (1950/1959, CW 9i, \|553).

As a symbolic reflection of the ambiguous nature of spirit, the figure of the magician sometimes appears as a couple, a white and a black magician. In her Jungian analysis of the fantasy-opus The Lord of the Rings, Pia Skogemann points out that the two wizards, Gandalf and Saruman, represent the positive and the negative aspects of spirit, and together they form the alchemical 
image of the double nature of spirit, the Mercurius Duplex $(2009,129)$. Gandalf signifies the life-giving aspect of spirit: "what gives life, stimulates, inspires, ignites, and unites" (129). Saruman, on the other hand, embodies spirit in its negative aspect. Saruman uses his magic and intelligence to control, seduce, and dominate the free people of Middle Earth, and his relationship with nature is that of exploitation and destruction. Saruman is motivated by a search for personal power, whereas Gandalf acts as a servant of life and an agent of inspiration and motivation, and he is able to lift the spirit of men and women even in the darkest of times.

In several places in the Collected Works, Jung discusses the duplex figure of the white and the black magician as it appears in a theology student’s dream $(1928 / 1966, \mathrm{CW} 7, \llbracket 287 ; 1954 / 1968$,

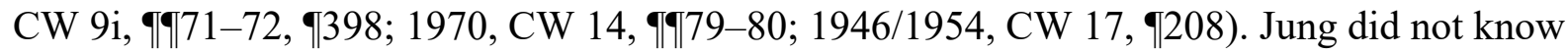
this young man personally; all we are told is that "he was in great straits because of his religious beliefs" (1954/1968, CW 9i, ๆ70). In the student's dream an old man appears, called the white magician, although he is dressed in black. Later another old man appears, identified as the black magician, although he is dressed in white. The white magician says that they need the help of the black magician, who has found the keys to Paradise as well as a dark horse who emerged from the grave of a king and a virgin. The black magician, for his part, needs the help of the white magician, who knows how to use the keys to Paradise. In this dream image, Jung sees reflected the Taoist thought that opposites are always interdependent and relative although they may appear unrelated and absolute: "the dream stresses the relativity of good and evil in a way that immediately calls to mind the Taoist symbol of Yin and Yang” (1928/1966, CW 7, $\mid 287)$. Elsewhere Jung states that the dream expresses "the uncertainty of all moral valuation, the bewildering interplay of good and evil, and the remorseless concatenation of guilt, suffering, and 
redemption" (1948/1959, CW 9i, $\{399)$. Jung’s commentary on this dream makes it clear that what appear as opposites on one level may, in fact, belong together on another. The psychological process of integrating the opposite pole of one's conscious outlook and moral standpoint is what Jung refers to as a union of opposites, and in the dream Jung sees a preparation for such a union: "The two antithetical magicians are obviously making ready the work of union” (1970, CW 14, 凤80).

In more concrete terms, this means that whereas spirit has a propensity to be split into opposing poles (symbolized by the white and the black magician), the work to unify opposites demands that we try to endure the tension of opposites in our own psyche. This means realizing that opposing viewpoints and worldviews can both hold elements of truth and value. For instance, human thinking may easily split into opposite ideological poles such as idealism versus materialism, communism versus capitalism, conservativism versus progressivism, atheism versus a religious worldview, and individualism versus collectivism. The list of potential contradictory principles is probably endless: "nothing in us ever remains quite uncontradicted, and consciousness can take up no position which will not call up, somewhere in the dark corners of the psyche, a negation or a compensatory effect, approval or resentment" (Jung 1970, CW 14, 9706). While each of these viewpoints holds some truth and value, none of them expresses a complete truth and something of value and validity can always be found in the opposing viewpoint. Whatever ideology, religion, or other type of cultural or individual value system one believes in and lives by, there will always be a contrasting set of values and ideals. Furthermore, the rejected spiritual pole will also exist as a rejected viewpoint somewhere in one's own psyche. This is the reality expressed in the double figure of the white and the black magician. The white 
magician represents the values and ideals that one believes in and tries to live by, and the black magician is the "spiritual shadow": the rejected counter-pole that must be integrated. The act of splitting ideas and value systems into good and bad has the benefit of easing tension in the psyche, since one pole of the opposite is projected onto somebody else "out there" whom we can then dislike and think of as morally or intellectually inferior.

As Jung points out, this leads to a certain relativity in regard to value judgements (1946/1954, CW 17, ๆ209). In other words, the fact that any philosophical, ethical, or ideological position always has an opposite that may be equally as valid may lead to a position that indiscriminately accepts all opinions and worldviews as equally valid. However, this line of thought does not lead to complete relativism, wherein all values and viewpoints are equally valid and valuable. This way of thinking has an inherent value that favors integration over splitting: a viewpoint or attitude that is able to include and hold the tension between opposite ideas and ideals is superior to a viewpoint that escapes this tension by splitting off one pole as inferior, unworthy, or evil. This leaves us with the question of whether all ways of thinking have equal value. Are all viewpoints contained in the figure of the black magician worthy of integrating, or should some attitudes about life be rejected? This question is one that I will discuss further in relation to the image of the white and the black magician as it appears in the Earthsea Cycle by Le Guin.

The Earthsea Cycle depicts a confrontation with the dark aspect of how we relate to spirit. In this case, the black magician does not stand for the sum of rejected but legitimate points of view but rather a negative, narcissistic use of spirit that detracts from life rather than adding to it. The story also shows how this confrontation with the black magician is necessary because it may 
transform our relation to spirit into an attitude, which can be called wisdom, as well as lead to the possibility of a more creative and life-affirming relation to spirit.

\section{$<1>$ The Wizard of Earthsea $<1>$}

The Earthsea Cycle began as a trilogy but eventually expanded to become five novels plus a collection of short stories. The setting of all the books is the medieval-style fantasy world of Earthsea, an imaginary realm of islands and archipelagos. The principal character is the man Ged, who in the first book, A Wizard of Earthsea, learns the art of magic and eventually becomes a wizard at the wizard school on the island of Roke.

A few words about the storyline of the novels are necessary for those readers who are not familiar with the Earthsea Cycle. The first novel, $A$ Wizard of Earthsea, follows Ged from when, as a young man, he discovers his magical abilities and is trained as a magician by the wise old man Ogion and later at the wizard academy on the island of Roke. In this book, Ged struggles with the darkness inside himself, which is symbolized by a creature referred to as the shadow. The second novel in the series, The Tombs of Atuan, follows a young high priestess, Tenar, who serves the dark powers of the earth. In this novel, Ged finds his way into the secret tombs of the priestesses, steals a hidden treasure, and brings Tenar away with him.

The third novel of the Earthsea Cycle is The Farthest Shore; in this book the motive of the white and the black magician is central. The book follows a young prince, Arren, who arrives at the wizard school on the magical island of Roke, to ask the council of wise old wizards for advice. Tragically, magic is disappearing from the islands of Earthsea. In the realm, magic is wielded by 
wizards and witches, but for an unknown reason, the magic words no longer work and the wielders of magic are forgetting the words of magical power: "the springs of wizardry have run dry" (Le Guin 2018, 255). But not only is magic disappearing; the inhabitants of Earthsea also seem to be losing joy in things such as singing, dancing, and playing, as well as their love of fine craftsmanship. There is a growing sense of loss of caring, meaning, and purpose; instead, a sense of hopelessness, aggression, and addiction is spreading. Even the dragons, who symbolize the wild, original force of creation, are losing their ability to speak as well as their intelligence; they are becoming raving and insentient animals. The wizards of Roke do not know the answer to the problem, and Ged, who is now the Archmage of Roke and an elder spellcaster, joins Arren on a long journey to find the cause of the strange malady befallen Earthsea.

They discover a powerful magician named Cob has discovered a way of attaining eternal life for himself as well as dominion over the ghosts of the dead. His dark sorcery is slowly draining the world of magic, meaning, and joy, and is the cause of the profound illness that is spreading throughout Earthsea.

\section{$<1>$ The White and the Black Magician of Earthsea $<1>$}

Ged and Cob represent the archetypal duplex figure of the white and the black magician. The good wizard, Ged, ventures to heal the world from the malady that the dark wizard, Cob, has created. Ged's moral goodness lies in his willingness to use his powers and skills and to endure trials and suffering for the sake of an ailing world. Cob's kingdom is the land of the dead, where Cob has made himself ruler of the souls of the dead. He is now a living dead being who can rule in this state for all of eternity. By using the most powerful magic, he has opened a rift between 
the land of the living and the land of the dead. This rift sucks the life and meaning out of the land of the living. Through an act of magic, Cob has become a shadow figure who lives in the land of the dead but can manifest in human form. When the body dies, he returns as a shadow and continues his existence unaffected. Cob seduces people to follow him, promising eternal life, but in reality, they live a shadow-life of madness and addiction. When Ged and Arren first meet Cob, he demands that they address him as Lord and meet him in his kingdom when it suits him (Le Guin 2018, 359).

The difference between the two magicians becomes clear during their conversation. Whereas Ged has embarked on his dangerous quest in service of the world around him, Cob has used his magic to gain power over others and to exalt himself as king. Hence, the will to power and the will to serve represent a difference between the light and the dark aspect of spirit:

"What is life, Cob?"

"Power."

"What is love?"

"Power." (Le Guin 2018, 371)

Dark magic is the use of power, not in the name of relationship or service to society, but for the sake of control and domination. In the story, it is magic used for the sake of power over others and the exaltation of oneself, resulting in a lifeless and meaningless world.

To Jung, the figure of the magician is closely connected with power; what defines the magician is his ability to use a magical power to influence the world around him. Jung discusses what he calls a "mana personality" - a charismatic person who can use charisma as well as peoples' 
projections onto him to influence others. According to Jung, such a person is influenced by the archetypal figure of the magician, which may bring both benefits and dangers (1928/1966, CW $7,9377)$. On the one hand, a society needs people who can inspire and help make sense of the world. On the other hand, the magician brings the danger of psychic inflation: "Thus he becomes a superman, superior to all powers, a demigod at the very least” ( $₫ 380)$. Charismatic people have the ability to influence and seduce others. In return, others' projections onto them may create an inflated sense of self and of their own importance. It is tempting to use one's power for egotistical purposes. To use power is neither good nor bad; the main question is whether this power is used creatively to achieve something (the power to) or whether it is used detrimentally to control, dominate, and seduce (the power over). The power to uses the influence of spirit to enrich and enhance life. The power over uses the influence of spirit to detract from life. By seeking to impose his will on people and nature, thereby refusing growth and life, Cob has made himself ruler of the dead and a lord of the land of the dead.

$<1>$ The Narcissistic Shadow $<1>$

The question of a positive (life-enhancing) and a negative (life-detracting) use of spirit is related to the question of narcissism. The way in which Cob uses his magic to exalt himself over others without any concern about the consequences of his actions for the lives of everyone in Earthsea has many similarities with the characteristics of narcissism. Cob repeatedly reveals his grandiose fantasies in stating his own power over others and his superiority to everyone else. He appears devoid of empathy with no concern that his prolonged life and enhanced power come at the cost of robbing the world of its beauty and meaning; his own need is what counts, not the needs of others. 
The origin of Cob's narcissism is related to an injury caused by Ged much earlier in their life. As the two magicians meet, Cob explains, "After you, in your pride, thought you had humbled me and taught me a lesson. Oh, a lesson you taught me, indeed, but not the lesson you meant to teach!” (Le Guin 2018, 370). We are not told anything about the specific circumstances of this prior meeting of the two magicians, but Cob's words show that his efforts to achieve immortality as well as domination over others are motivated by the injury to his pride and self-esteem and the fear of ever again experiencing a humiliating defeat.

\section{$<1>$ Positive Narcissism $<1>$}

The moral of the story of Ged is not that the use of power is negative, or that the enjoyment of power is inherently negative. As Archmage of Roke, Ged holds considerable power in the world of wizardry, and it is clear that he enjoys using his magical abilities:

Arren would watch the mage as he stood up and with voice and hand called those clouds to drift toward them and to loosen their rain down on their boat. The lightning would leap among the clouds, and the thunder would bellow. Still the mage stood with upraised hand, until the rain came pouring down on him and on Arren and into the vessels they had set out and into the boat and onto the sea, flattening the waves with its violence. He and Arren would grin with pleasure, for of food they had enough, if none to spare, but water they needed. And the furious splendor of the storm that obeyed the mage's word delighted them. (Le Guin 2018, 341)

At some point Arren asks why Ged's magic is not afflicted by the illness spreading in the world, and Ged answers: 
"Because I desire nothing beyond my art." And after some time he added more cheerfully, "And if I am soon to lose it, I shall make the best of it while it lasts." There was indeed a kind of lightheartedness in him now, a pure pleasure in his skill, which Arren, seeing him always so careful, had not guessed. (341)

This joy in his art and power is close to the attitude that Kohut (1966) describes as healthily developed narcissism. As an example of this attitude, Kohut mentions creative activity and work, in which the narcissistic energies of the self are heavily invested (cathected). The creative individual (whether an artist, scientist, artisan, or intellectual) may also experience such a strong emotional investment in the shaping of the object of their work that it resembles a love affair and even an addiction. This type of "positive narcissism" is related to the natural grandiosity and self-love that children, in particular, may exhibit when they shine with pride and joy over their parents' praise of however small an accomplishment. This natural and positive kind of being in love with oneself and one's abilities can, if mirrored and allowed to unfold by the child's significant others, develop into a creative relationship between the self and the external world. This kind of narcissism is significantly different from the negative narcissism that Cob symbolizes. Its function is not to dominate or control others and exalt oneself but rather to express the inspiration from the living spirit by means of body, voice, or other types of expression such as art or writing. At the root of negative narcissism is an attempt to protect a vulnerable part of the self against ever experiencing humiliation and injury, whereas positive and life-affirming narcissism has its origin in the expression of a living, personal spirit that may be enriching to both the individual and the surrounding community.

\section{$<1>$ The Confrontation $<1>$}


Toward the end of the trilogy, Ged and Arren journey to the land of the dead where they find and confront Cob. This final confrontation does not take place as an epic spectacle of two powerful wizards throwing earth-shattering spells at each other. Rather, it is a dialogue in which Ged lets Cob see what he has lost in his search for power and eternal life; he has lost his name (his identity) and his life in the world of the living. Cob realizes the emptiness of who he has become and what he has attained.

The question is how Ged wins this "victory" over the powerful Cob. Ged is not more powerful as a magician, but he has an advantage over Cob. In the first book of the Earthsea Cycle ( $A$ Wizard of Earthsea), Ged is on the run from this shadow of greed, pride, ambition, vanity, and lust for power, until he finally comes face to face with it. In The Farthest Shore Ged recounts this story to Arren:

I know how much evil one man, one life, can do. I know it all too well. I know it because I have done it. I have done the same evil in the same folly of pride. I opened the doors between the worlds just a crack, just a little crack, just to show that I was stronger than death itself. (Le Guin 2018, 344)

In the end, Ged confronts and "defeats" his persecuting shadow, not by fighting it, but by owning it; he calls his shadow by his own name, "Ged," and it becomes a part of him. Because Ged has owned his personal shadow he can resist being caught up in the power complex that Cob presents to him. Ged manages to meet Cob on another level. He understands what drives Cob, because he knows this drive within himself. Ged can meet Cob with an attitude of empathy and understanding, because he knows that if he had succumbed to the power drive within himself, it could have been he who lost his soul to gain power and eternal life. Ged also understands Cob's 
desire to escape death, and he tells Arren that Cob is actually not so different from himself or, indeed, from all of us. According to Ged, we all know Cob's alluring voice, which he describes in this way: "The traitor, the self; the self that cries I want to live; let the world burn so long as I can live! The little traitor soul in us, in the dark, like the worm in the apple" (343). According to Ged, Cob's voice speaks most clearly to people who follow the inspiration from spirit on their path of individuation:

He talks to all of us. But only some understand him. The wizards and the sorcerers. The singers; the makers. And the heroes, the ones who seek to be themselves. To be one's self is a rare thing and a great one. To be one's self forever: is that not better still? (343) Perhaps because the path of individuation is connected to the self by the voice of the spirit, the danger of inflation is all the greater. Since he has wrestled with his own narcissistic shadow, Ged knows this truth and is, therefore, able to recognize the danger and stay out of his own shadow of narcissism, grandiosity, and fear of death.

Ged ultimately wins the confrontation because he speaks to the hole in Cob's soul that his search for power has cost him. In exchange for a kind of eternal shadow-life, Cob has created an emptiness within himself that he seeks to fill by drawing the whole world into himself and ruling it:

You sold the green earth and the sun and the stars to save yourself. But you have no self. All that which you sold, that is yourself. You have given everything up for nothing. And so now you seek to draw the world to you, all that light and life you lost, to fill up your nothingness. But it cannot be filled. Not all the songs of the earth, not all the stars of heaven, could fill your emptiness. (Le Guin 2018, 372) 
The only word that Cob manages to say in response is "Life" (372). The hole in Cob's soul is similar to what Kohut describes as the fiercely defended space behind the narcissist's persona (Kohut 1977/2009). Kohut reminds us that behind narcissism lies a tragic emotional wound as well as "low self-esteem and depression-a deep sense of uncared-for worthlessness and rejection, an incessant hunger for response, a yearning for reassurance. . . . a feeling of inner deadness and depression" (5). When Cob is brought in touch with the sense of deadness and emptiness that lies behind his grand machinations and grandiose persona, he collapses and loses most of his power. He is finally defeated by Ged and Arren. In the end, Arren slays Cob with his sword. It is by means of a discriminating act of conscious will (the sword) that the negative aspect of how we use spirit must be rejected. Before they begin the journey back to the land of the living, Ged closes the rift between the land of the dead and the land of the living, which Cob had opened. However, this act costs Ged all of his magical powers, and as he returns from the journey he is no longer a magician.

\section{$<1>$ The Transformation of Spirit into Wisdom $<1>$}

The story of Ged after he returns from the adventure is a tale of how spirit can be transformed into wisdom. Even before the loss of his magical powers, Ged was preparing himself for coming to terms with a way of life that is less concerned with trying to influence the world and more concerned with accepting life as it comes. Sailing in their small boat on the big ocean, Ged says to Arren:

You were born to power, Arren, as I was; power over men, power over men's souls; and what is that but power over life and death? You are young, you stand on the borders of possibility. ... But I, who am old, who have done what I must do, who stand in the 
daylight facing my own death, the end of all possibility, I know that there is only one power that is real and worth the having. And that is the power, not to take, but to accept. (Le Guin 2018, 344)

After returning from the land of the dead, Ged faces a life without any special powers and with no social position. It is as if all the power has been transferred from the mage (and thus the archetype of spirit) to the more worldly matters of the king. In the fourth novel of the Earthsea series, Tehanu, Ged lives a humble life in near poverty after returning to his native island Gont. For a long time Ged's behavior and mood seem that of someone who is severely depressed and despondent. The journey through the land of the dead, his confrontation with Cob, and the loss of his magical powers and status as Archmage have left him without a sense of purpose and identity. After his arrival in the hut where Tenar lives, Ged has clearly lost the vitality and energy he used to have:

He sat on the threshold, looking out into the day, and Tenar, coming around the house, looked at him. He still had an ashy, shadowy look to him. It was not the grey hair only, but some quality of skin and bone, and there was nothing much to him but that. There was no light in his eyes. (434-435)

In the last two novels, Ged rejects playing any further role in the history and events of Earthsea. Now King Arren, a young mage named Alder, and Tenar and her adoptive daughter Tehanu are the main characters of the story. After a while, Ged seems to accept his new and much more mundane life. Even though Ged has apparently lost all of his magical powers as well as his social status and position, he has gained something else. Previously, when he was magician and Archmage of Earthsea, he instructed his young companion, Arren, about the importance of 
upholding the balance of the world and not using magical powers to disturb this balance. After his return from the quest, Ged withdraws from the grand events of the world. He is just an old man living with his wife in a poor hut surrounded by sheep and chickens. Now Ged neither interferes with the events of the world nor disturbs the flow of life.

Le Guin writes about Ged in this period of his life: “In Tehanu, Ged's virtues are no longer the traditional male heroic ones: power as domination over others, unassailable strength, and the generosity of the rich" (Le Guin 1993, 14). But what virtues does this old man then possess?

After Ged and Arren's great deed, we do not hear much about Ged. He lives for a while with Tenar in the small hut, but he then decides to work as a goatherd in the mountains as a way of coming to terms with his new life. He returns to Tenar at a crucial moment, however, just as Tenar and her foster child, Tehanu, are being attacked one night by a group of men. Ged runs a pitchfork through one of the men and scares the rest of them away. Later, Tenar speculates how Ged managed to return at just the right moment to spot the men on their way to Tenar's house: "I think you were there on that road, just there just then, because of that—because that is what happens to you. You didn't make it happen. You didn't cause it. It wasn't because of your 'power.' It happened to you. Because of your-emptiness.". . And after a while Ged replies: "This isn't far from what I was taught as a boy on Roke: that true magery lies in doing only what you must do. But this would go further. Not to do, but to be done to ...". And Tenar says: "I don't think it is quite it. It's more like what true doing rises from.” (Le Guin 2018, 525) 
Here, Ged and Tenar express something quite close to a Taoist philosophy, which emphasizes action in such harmony with the flow of life that it almost appears as passivity or nonaction. The Taoist term that most closely expresses this way of being is the philosophy of $W u W e i$, which can be translated as "doing without doing" or "effortless action" (Slingerland 2000). Wu Wei expresses an ideal of how to live and act from a state of concordance with the situation, which means that actions do not spring from decisions made by the rational mind but rather actions emerge out a graceful sense of what must simply be done at that moment. In his discussion of Wu Wei, Slingerland mentions that in the state of Wu Wei body and mind, actions and thoughts are not separated but work in tune with one another. In this ideal state actions spring from "the embodied mind" (300). This points to a theme that has not yet been discussed adequately here, the relation between body and spirit.

In his discussions of the figure of the black magician, Jung mentions that the black magician is connected with the body and its biological instincts and passions (1948/1959, CW 9i). The white magician symbolizes a relationship with spirit in which body and spirit are not connected. Spirit has become purely mental and thus works disconnected from the bodily and physical aspects of life. In Wu Wei, body and spirit act in unison and the lack of separation and struggle between the two gives actions a feeling of effortlessness. Perhaps Ged's journey to the Land of the Dead was also the journey of spirit into matter and the body, which from the point of view of spirit uninhibited by the weight of flesh and bones, must at first seem like a kind of dying.

Significantly, at this stage, Ged is not a magician anymore because he has lost his magical powers. Magicians are characterized by their ability to influence the world by means of the 
power they wield over the hearts and minds of people. At this stage of his life, Ged is an image of spirit as the wise old man who has learned to live and act less from the conscious will and ambitions of the ego and more from the deeper parts of the personality where world and self are less separated.

\section{$<1>$ The Rejuvenation of Earthsea $<1>$}

Whereas Cob did not have many traits worthy of integration, according to Jung, the figure of the black magician holds the keys to individuation. At the beginning of The Farthest Shore, we learn that the throne of the king has been empty for eight hundred years. One of the magicians of Roke exclaims:

Eight hundred years has the heart of the world been empty! We have the crown, but no king to wear it. ... Let there be a king upon the throne, and we will have peace, and even in the farthest Reaches the sorcerers will practice their arts with untroubled minds, and there will be order and a due season to all things. (Le Guin 2018, 265)

Only after Ged's and Arren's confrontation with Cob is the realm of Earthsea revitalized by again having a king on the once-empty throne at the center of the kingdom. In the next book of the series, Tenahu, we learn that because of the new king, order, peace, and prosperity are spreading among the islands of the kingdom. Perhaps the problem in Earthsea was that the magical island of Roke and its magicians' college were too well protected by the magical "Roke wind," an ever-shifting labyrinth in front of the college, along with its impenetrable walls and a mysterious doorkeeper. The magic of Roke needed to enter the world in order to enrich and give meaning to its everyday life. 
For Ged and Arren, this meant a confrontation with the archetypal shadow aspect of spirit, which is connected with using "the power of spirit" (that is, the power of words and ideas) to influence the external world. As soon as the spirit leaves the internal world of personality to influence the external world, questions of narcissism and power arise. If we are to make a difference in the external world of people, things, politics, and organizations, our personal spirit must be put to use "out there." To do this we need some of the power of the black magician. As we integrate this power, we begin to withdraw projections from people and institutions "out there" that we may have perceived as powerful, menacing, or frightening. In the process, the power of the black magician becomes less identified with outer figures such as "the system," "the powers that be," or our boss at work, and more an aspect of our own ability to influence the world around us. However, the moment we begin to integrate this power (the influence that our words and thoughts may have on the world around us), then we are faced with the question of our own narcissism and drive for power: "Am I influencing the world in the right way and for the right reasons?"

Although the black magician may hold the key to individuation, it is important to note that at the end of the story Cob was not redeemed and brought back from the land of the dead; he was killed by Arren's sword, a symbol of conscious discrimination. As Ged says to Prince Arren: "One man may as easily destroy as govern: be King or Anti-King" (343). If we are not to become "antikings" we must discriminate between, on the one hand, a use of our personal power that serves our own negative narcissism and controlling impulses and, on the other hand, our natural desire to create a good life for ourselves while enjoying whatever skills we have (positive narcissism) and a creative impulse that may enrich our lives and the world around us. 
$<1>$ Conclusion $<1>$

To conclude these investigations, I return to the dream at the beginning of this article, which sparked my curiosity about the nature of the two magicians. In my dream the black magician represents all the perspectives and worldviews that I have come to reject, disavow, and speak against. I was brought up to be a liberal person with anti-authoritarian values. The black magician, then, represents the right wing and conservative values, whose perhaps valid viewpoints and valuable points-of-view I have rejected and repressed in myself and who therefore haunts me in the unconscious. In my adult life, I work in a university and often speak in public. During my career as a lecturer and speaker, I have often felt the need for a powerful adversary to criticize and speak out against. Over the years, I have used nationalism, ethnocentrism, class-society, authoritarianism, neoliberalism, and, recently, materialism as (real or imaginary) opponents to formulate my own oppositional perspectives. I suspect this pattern of speaking out against anonymous but powerful and unjust adversaries is related to the fact that I lost contact with my father when I was three years old. Behind all my written and verbal struggles against (perceived or real) powerful viewpoints is the rejection of a father who went away: "Since I can't have your presence and love, father, I am going to reject and hate you!" Of course, behind this rejection there is a repressed longing for a present and loving father figure as well as an unformulated question: "Father, why did you leave me?" After all, Jung writes that spirit in a person is often related to the father complex (1948/1959, CW 9i, $\mid 396)$, which seems to be true in my case. I also notice the similarity with the case of Cob. In both cases, the origin of the black magician was a painful wound to the self, inflicted by a paternal figure. 
To come full circle I would like to finish with another dream, which came to me in the latter stages of writing this article. What I will present here is the ending of a dream, in which the first part was full of images of me fighting with different persons, men and women, which symbolizes my struggles with various (real or imagined) adversaries:

I am with three or four other men outside a house. An evil black magician appears, and it feels very dangerous. We build a fire in order to do some kind of ceremony. I spot the evil magician and leave the bonfire in order to throw stuff at him. Suddenly he looks like a two-dimensional figure made of playdough. The other men tell me to hurry back so I do not miss my time in the ceremony. It has something to do with ayahuasca or something like that.

In this dream, the black magician is reduced to a two-dimensional figure that is no longer as threatening as in the first dream. The fact that the black magician is now two-dimensional could mean that my ideological opponents "out there" are not actually real, but rather constructs of internal splitting and projections. The fact that the figure is made of playdough points to the childhood origins of the split and the creation of the black magician as an inner figure. In the dream the black magician is still there, but now I can stop fighting with him and instead participate in a creative relationship with spirit, which is more likely to bring something new and inspirational into the world than have my struggles with more or less imaginary ideological opponents.

$<$ ACK $>$ ACKNOWLEDGMENTS 
I wish to thank Jungian analyst and pastor Henriette Heide-Jørgensen, $\mathrm{PhD}$, Jungian analyst Murray Stein, $\mathrm{PhD}$, and Jungian analyst Jeffrey Moulton Benevedes, $\mathrm{PhD}$, for their valuable comments and helpful suggestions about this article. $<\mathrm{ACK}>$

$<$ NOTE $>$ NOTE

References to The Collected Works of C. G. Jung are cited in the text as CW, volume number, and paragraph number. The Collected Works are published in English by Routledge (UK) and Princeton University Press (USA). $<$ NOTE $>$

\section{$<$ BI $>$ BIBLIOGRAPHY}

Gitz-Johansen, Thomas. In press. “Jung and the Spirit: A Review of Jung’s Discussions of the Phenomenon of Spirit." Journal of Analytical Psychology.

Granrose, John. 1996. “The Archetype of the Magician.” Diploma thesis, C. G. Jung Institute, Zürich.

Jung, C. G. 1926/1960. “Spirit and Life.” The Structure and Dynamics of the Psyche. CW 8.

—. 1928/1966. "The Relations between the Ego and the Unconscious." Two Essays on Analytical Psychology. CW 7.

—.1931/1960. "Basic Postulates on Analytical Psychology." The Structure and Dynamics of the Psyche. CW 8.

—. 1946/1954. "Analytical Psychology and Education.” The Development of Personality. CW 17.

-1948/1959. "The Phenomenology of the Spirit in Fairytales." The Archetypes and the Collective Unconscious. CW 9i. 
_. 1950/1959. “A Study in the Process of Individuation.” The Archetypes and the

\title{
Collective Unconscious. CW 9i.
}

—. 1954/1968. "The Archetypes and the Collective Unconscious." The Archetypes and the

\author{
Collective Unconscious. CW 9i.
}

1970. Mysterium Coniunctionis. CW 14.

-1989. Nietzsche's Zarathustra: Notes of the Seminar Given in 1934-1939. London:

Routledge.

Kohut, Heinz. 1966. "Forms and Transformations of Narcissism." Journal of the American Psychoanalytic Association 14: 243-272.

_. 1977/2009. The Restoration of the Self. Chicago: University of Chicago Press.

Knox, Jean. 2003. Archetype, Attachment, Analysis: Jungian Psychology and the Emergent Mind. Hove \& New York: Brunner / Routledge.

Le Guin, Ursula K. 1993. Earthsea Revisioned. Cambridge: Children's Literature New England.

-2018. The Books of Earthsea: The Complete Illustrated Edition. London: Orion Publishing Group.

Merchant, John. 2006. “The Developmental/Emergent Model of Archetype: Its Implications and Its Application to Shamanism.” Journal of Analytical Psychology 51, no. 1: 125-144.

_ 2019. "The Controversy around the Concept of Archetypes and the Place for an Emergent/Developmental Model.” Journal of Analytical Psychology 64, no. 5: 701-719.

Moore, Robert, and Doug Gillette. 1991. King, Warrior, Magician, Lover. New York: HarperOne.

Skogemann, Pia. 2009. Where the Shadows Lie: A Jungian Interpretation of Tolkien's The Lord of the Rings. Asheville, NC: Chiron Publications. 
Slingerland, Edward. 2000. "Effortless Actions: The Chinese Spiritual Ideal of Wu-wei." Journal of the American Academy of Religion 68, no. 2: 293-328. $<\mathrm{BI}>$

$<$ BIO $>$ Thomas Gitz-Johansen, PhD, is associate professor in Educational Studies at Roskilde University and senior candidate at the C. G. Jung Institute in Copenhagen. He is the author of the following articles: "Jung in Education: A Review of Historical and Contemporary Contributions from Analytical Psychology to the Field of Education" (Journal of Analytical Psychology 61, no. 3), "Bruce Springsteen as a Symbol: Containment, Fatherhood, and Manhood" (Jung Journal: Culture \& Psyche12, no. 1), and "Jung and the Spirit: A Review of Jung's Discussions of the Phenomenon of Spirit" (Journal of Analytical Psychology, in press), as well as a number of books and articles about education and childhood. Correspondence: gitz@ruc.dk. $<$ BIO $>$

\section{$<$ AB $>$ ABSTRACT}

Jung often discussed the phenomenon of the human spirit, emphasizing its ambiguous nature; it may work for good as well as for evil. This article engages with the ambiguous nature of spirit through a discussion of the double-figure of the white and the black magician. The black magician represents the dark side of the work of the human spirit—our narcissism and power drive. In the process of individuation, we must confront this figure, if we are to use spirit in a way that enriches our lives and the world in which we live. $<\mathrm{AB}>$

\section{$<$ KW $>$ KEY WORDS}

Earthsea, Le Guin, magic, magician, narcissism, power, spirit, splitting, wisdom $<\mathrm{KW}>$ 